\title{
Teacher Corrective Oral Feedback in the Classroom
}

\author{
Nasy Inthisone Pfanner \\ B.O.RG Dornbirn-Schoren
}

\begin{abstract}
Correspondence concerning this article should be addressed to Nasy Inthisone Pfanner, secondary school B.O.RG Dornbirn-Schoren, Höchsterstraße 32, Dornbirn, Austria, 6850.

E-mail: nasypfanner@gmail.com
\end{abstract}

\begin{abstract}
The article reports on a study of teacher corrective oral feedback in Iris Becker Elementary School, a public school serving pupils from kindergarten- $5^{\text {th }}$ grade in Dearborn, Michigan. Some researchers claim that teacher corrective oral feedback is beneficial to L2 learning while others discard its merit. This study is an attempt to explore this topic further with young learners. The method used in the study included one classroom observation. The participants included one mainstream classroom teacher and about 25 students. The results show high teacher corrective oral feedback.
\end{abstract}

Keywords: corrective feedback, error treatment, oral feedback, English as Second Language, second language acquisition

The benefits of teacher corrective oral feedback are controversial. While some researchers (Aljaafreh and Lantolf, 1994, Higgs and Clifford, 1982, Bley-Vroman, 1994, Hammerly, 1987, Chaudron, 1988, White, 1991, Schwartz, 1993, DeKeyser, 1994, Schmidt, 1990, Lyster and Panova, 2002) point out the positive effects of teacher corrective oral feedbacks in the classroom, other researchers (Hendrickson, 1978, Larsen-Freeman 2000, Lightbown, 1991, Lightbown and Spada, 1993 and 2006, Doughty and Varela, 1998) doubt them. Han (2002) believes that depending on how it is used, it could be beneficial. Or as Lochtman (2002) puts it, the importance of teacher corrective oral feedback is much discussed.

There are many pupils who struggle with learning and it is common practice for teachers to give corrective oral feedbacks. The purpose of this study is to investigate the different types of corrective oral feedback and determine which types lead to student repair and which types do not lead to student repair. Unlike previous studies that have investigated laboratory like settings, this study examined real school settings. Results obtained in this experiment can help educators make better decisions regarding the use of corrective oral feedback. Ultimately, the goal is to help pupils learn better.

\section{Materials and Methods}

Corrective feedback (CF) is defined as "any reaction of the teacher which clearly transforms, disapprovingly refers to, or demands improvement of the learner utterance" (Lyster \& Panova, 2002, p. 574). The notion that learners may need negative evidence such as error feedback or explicit instruction has presently lead to the eminence of CF studies in English as a Second Language (ESL) and other L2 education contexts (Lyster \& Panova, 2002, p. 573). The reasons for studying CF include claims about the significance of negative feedback in grown-ups (Ellis, 2004, p. 236). According to Doughty and Williams (1998) the role of $\mathrm{CF}$ in the process of learning a foreign language is still much debated (Lochtman, 2002, p. 272) and opinions on the purpose of CF can be very mixed or split (Han, 2002, p. 1).

Researchers such as Hendrickson (1978) and Larsen-Freeman (1981) made the following claims about errors and corrections: 1) errors are a natural result of the communication development skills, 2) correction distracts the learner's attention from the communicative task, 3) correction forces the learner to focus on the form instead of the meaning and 4) correction activates the learner's affective filter, which 
blocks learning. These assumptions lead teachers to ignore errors in classrooms (Han, 2002, p. 2). A study by Doughty (1994) on CF found that the teacher gave approximately half of the feedback to students' incorrect utterances (Lyster \& Panova, 2002, p. 576). Theoretically speaking, corrective feedback is capable of advancing the learning process, but that is not always true in practice (Han, 2002, p. 9). Doughty and Varela (1998), Lightbown (1991), Lightbown and Spada (1990) and White (1991) considered CF as having little importance in the classroom. Some research showed that early form-focused instruction might make it harder rather than easier for learners to discover the underlying structure of the target language and it has been suggested that form-focused instruction and CF can lead only to temporary and/or superficial changes in learner performance (Lightbown \& Spada, 1993, p. 206).

Researchers such as Higgs and Clifford (1982) and Hammerly (1987) argued that L2 learners exposed to natural language acquisition or communicative language teaching without error correction and form focus will eventually stop learning. Some SLA researchers, such as Bley-Vroman (1986), White (1991) and Schwartz (1993) considered CF to be necessary for second language learning. Dekeyser (1994) and Schmidt (1994) regarded CF as an essential element of explicit teaching that tries to make the learner be aware of the formal features of the input and help them see the difference between these features and those in their own interlanguage. Chaudron (1988) claimed that for most learners, CF may be the most successful source of improvement in target language development (Han, 2002, p. 7). Swain (1995) stated, "An additional effect of CF may be the enhancement of learners' metalinguistic awareness" (Lyster \& Panova, 2002, p. 574). Han (2002) acknowledged $\mathrm{CF}$ as especially indispensable in classroom SLA (p. 24). Evidence from previous studies showed that CF seems to advance learning (Aljaafreh \& Lantolf, 1974, p. 466).

Corrective feedback is classified into six types: 1) explicit correction, 2) recasts, 3) clarification requests, 4) metalinguistic feedback or clues (as stated in Gibbons, 2006, p. 52), 5) elicitation, and 6) repetition of error (Lyster \& Panova, 2002, p. 576), all of which were the focus of this research. While most corrective oral feedback does fall into the above categories they do not cover all types of oral feedback.

1. Explicit Correction: It refers to the explicit provision of the correct form and generally is needed for treating learning problems that are categorized as error (Han, 2002, p. 14). As the teacher provides the correct form, he/she clearly indicates that what the student had said was incorrect. Carroll and Swain (1974 cited in Aljaafreh \& Lantolf, 1974, p. 466) demonstrated that learners who received explicit correction overall are superior on experimental assignments than the learners who received implicit feedback. Example of explicit correction:

S: The day . . . tomorrow. (lexical error)

$\mathrm{T}$ : Yes. No, the day before yesterday. (explicit correction) (Lyster \& Panova, 2002, p. 584).

2. Recasts: Recast involve the teacher's reformulation of student's entire speech or some of it without the error (Lyster \& Ranta, 1997, p. 46). Long (1996) defined recasts as implicit CF that reformulates/ builds an incorrect/incomplete speech clearly, parallel to the type of recasts used by caregivers in a child's first language acquisition (Lyster \& Panova, 2002, p. 582). Recasts also include translations in response to a student's use of the L1 (Lyster \& Ranta, 1997, p. 47). Recasts are by and large implicit and are not presented by such phrases "You mean," "Use this word," and "You should say." Some recasts focus on one word, however, some combine the grammatical or lexical modification as part of discourse. Recasts do not promote immediate learner repair (Lyster \& Panova, 2002, p. 577). Example of Recast:

S. . . I l looking for my pen.

T: You are looking for your pen. (Lyster \& Panova, 2002, p. 575).

3. Clarification Requests: based on Spada and Fröhlich (1995) clarification requests indicate to students that their speech has been misjudged by the teacher or that the speech is somehow incorrect and needs a reiteration or a reformulation. Clarification requests can deal with problems in either understanding or accuracy, or both (Lyster \& Ranta, 1997, p. 47) and often seek clarification of the meaning as well (Lyster \& Panova, 2002, p. 583).

S: I want practice today, today. (grammatical error)

T: I'm sorry? (clarification request) (Lyster \& Panova, 2002, p. 583).

4. Metalinguistic Feedback or Clues: In this type of feedback, the teacher asks questions or offers comments or information connected to the formation of the student's utterance without supplementing the correct form. For example, the teacher may say, "Do we say it like that?" "That's not how you say it in French," and "Is it feminine?"

$\mathrm{S}:$ Euhm, le, le éléphant. Le éléphant gronde. "Uhm, the, the elephant. The elephant growls."

(multiple errors)

T: Est-ce qu'on dit le éléphant? "Do we say the elephant?"

(de Gortari \& Tedick, 1998, p. 2).

5. Elicitation: It concerns with the methods that teachers use to acquire the correct form out of the student. There are three methods of elicitation: the teacher 1) allows for "fill in the blank," stops and allows the learner to finish the teacher's speech i.e., "No, not 
that. It's a . . ", 2) invites an open question "How do we say X in French?", and 3) requires a reformulation of the incorrect speech (Lyster \& Ranta, 1997, p. 48). Elicitation is further illustrated in the example below:

T: OK. Did you like it?

S: Yes, yes, I like it.

T: Yes, I . . .?

S: Yes, I liked it.

T: Yes, I liked it. (Lyster \& Panova, 2002, p. 575).

6. Repetition of Errors: It refers to the teacher's reiteration without connection to the student's incorrect speech. For the most part, teachers adapt their articulation to emphasize the mistake (Lyster \& Ranta, 1997, p. 48). For example, the teacher repeats the error below:

S: Le... le girafe? (gender error) "The...the giraffe?”

$$
\begin{aligned}
& \text { T: Le girafe? } \\
& \text { (de Gortari \& Tedick, 1998, p. 2) }
\end{aligned}
$$

Table 1

MEAP results

\begin{tabular}{lrrr}
\hline & & Iris Becker & State Average \\
\hline Reading: & Grade 3 & $97 \%$ & $86 \%$ \\
\hline & Grade 4 & $71 \%$ & $85 \%$ \\
\hline & Grade 5 & $86 \%$ & $82 \%$ \\
\hline Writing: & Grade 3 & $74 \%$ & $57 \%$ \\
\hline & Grade 4 & $45 \%$ & $45 \%$ \\
\hline Math: & Grade 5 & $60 \%$ & $59 \%$ \\
\hline & Grade 3 & $97 \%$ & $90 \%$ \\
\hline & Grade 4 & $93 \%$ & $86 \%$ \\
\hline & Grade 5 & $94 \%$ & $74 \%$ \\
\hline
\end{tabular}

Table 2

Ethnicity

\begin{tabular}{lrr}
\hline & Iris Becker & State Average \\
\hline White & $99 \%$ & $70 \%$ \\
\hline African American & $<1 \%$ & $20 \%$ \\
\hline
\end{tabular}

Table 3

Eligibility for free or reduced-price lunch

\begin{tabular}{lr}
\hline Iris Becker & State Average \\
\hline $85 \%$ & $37 \%$ \\
\hline
\end{tabular}

Source: MI Dept. of Education, 2007-2008
In a study by Lyster and Panova (2002) with a database of 1,716 student turns and 1,641 teacher turns the feedback types used were distributed as follows: 1) explicit correction $2 \%, 2$ ) recasts roughly $77 \%, 3)$ clarification requests $11 \%$, 4) metalinguistic feedback or clues $5 \%, 5$ ) elicitation $4 \%$, and 6 ) repetition of error 1\% (p. 586). Similarly, Scott (2008), a University of Auckland graduate with a double major in English and Linguistics and contributing writer of Suite 101. com, an interactive online magazine on 400 subjects for over 10 years wrote, "In a normal one hour lesson, a teacher will approximately use $55 \%$ recast feedback, $14 \%$ elicitation feedback, $11 \%$ clarification feedback, $8 \%$ metalinguistic feedback, $7 \%$ explicit correction, and $5 \%$ repetition feedback."

Lyster and Ranta(1997)reasoned that metalinguistic feedback, elicitation, clarification requests, and repetition allow more learner participation than recasts and explicit correction do (Lyster \& Panova, 2002 , p. 577). Scott (2008) stated that recasts and explicit correction do not lead to repair because they already provide correct forms to learners.

\section{Research Methodology}

This study includes a classroom observation to determine which types lead to student repair and which types do not lead to student repair. This method was chosen because it offered an opportunity to see first-hand interaction between teachers and students during a regular lesson.

\section{Student Body}

To better understand the student body, their academic strength and social economic status the students': 1) Michigan Educational Assessment Program (MEAP) results (scale: \% at or above proficient), 2) ethnicity, and 3) eligibility for free or reduced-price lunch is compared to the state average.

\section{Observation Procedure}

During the observation the class was working on the story of Brothers and Sisters by Ellen B. Senisi. The teacher discussed the story with the students, walked around the classroom, asked many questions and the students actively participated by raising hands to give answers. Some students participated more than others, but the teacher also asked the students who did not raise their hands to participate. Overall, the class had an active discussion of Brothers and Sisters and all students were involved (see table below). The observer sat in the back of the classroom, took notes and recorded the teaching on a cassette player. The students were not bothered nor paid any attention 
to the observer. The teacher had a good classroom Later in the evening, the recording was transcribed and management and there was no disciplinary problem. compared to the notes taken.

Table 4

Iris Becker Elementary School Observation

\begin{tabular}{|c|c|c|c|c|}
\hline & feedback types & $\begin{array}{l}\text { student } \\
\text { response }\end{array}$ & teacher feedback & context \\
\hline 1 & --- (I didn’t hear) & $\begin{array}{l}\mathrm{xxx} \\
\text { (unintelligible) }\end{array}$ & families helping one another & $\begin{array}{l}\text { discussing Brothers and } \\
\text { Sisters }\end{array}$ \\
\hline 2 & $\begin{array}{l}\text { non-corrective } \\
\text { repetition, } \\
\text { acknowledgement }\end{array}$ & $\begin{array}{l}\text { pictures } \\
\text { of brothers and } \\
\text { sisters }\end{array}$ & $\begin{array}{l}\text { you see pictures of brothers, } \\
\text { yes }\end{array}$ & $\begin{array}{l}\text { discussing what is in the } \\
\text { book }\end{array}$ \\
\hline 3 & $\begin{array}{l}\text { non-corrective } \\
\text { repetition, } \\
\text { acknowledgement }\end{array}$ & $\begin{array}{l}\text { they look like } \\
\text { they are mad } \\
\text { at each other }\end{array}$ & $\begin{array}{l}\text { okay, they look like they're } \\
\text { mad at each other }\end{array}$ & $\begin{array}{l}\text { discussing pictures } \\
\text { of children who don't } \\
\text { seem happy }\end{array}$ \\
\hline 4 & $\begin{array}{l}\text { non-corrective } \\
\text { repetition, } \\
\text { clarification } \\
\text { requests, } \\
\text { metalinguistic } \\
\text { feedback/clues }\end{array}$ & $\begin{array}{l}\text { they look like } \\
\text { they are having } \\
\text { fun }\end{array}$ & $\begin{array}{l}\text { they look like they are having } \\
\text { fun, what are they doing }\end{array}$ & $\begin{array}{l}\text { discussing various pictures } \\
\text { where the children play } \\
\text { together }\end{array}$ \\
\hline 5 & $\begin{array}{l}\text { clarification } \\
\text { requests }\end{array}$ & $\begin{array}{l}\text { it looks like it's } \\
\text { the mom }\end{array}$ & $\begin{array}{l}\text { how can you tell this is } \\
\text { the mom }\end{array}$ & discussing page 129 \\
\hline 6 & $\begin{array}{l}\text { non-corrective } \\
\text { repetition, } \\
\text { acknowledgement }\end{array}$ & they help & they help one another, okay & $\begin{array}{l}\text { discussing what brothers } \\
\text { and sisters do }\end{array}$ \\
\hline 7 & $\begin{array}{l}\text { clarification } \\
\text { requests, } \\
\text { metalinguistic } \\
\text { feedback/clues }\end{array}$ & $\begin{array}{l}\text { her mom is } \\
\text { having a baby }\end{array}$ & $\begin{array}{l}\text { how can you tell her mom has } \\
\text { a baby }\end{array}$ & discussing page 130 \\
\hline 8 & $\begin{array}{l}\text { non-corrective } \\
\text { repetition, recasts }\end{array}$ & $\begin{array}{l}\text { the same baby is } \\
\text { growing older }\end{array}$ & $\begin{array}{l}\text { oh, this is the same baby } \\
\text { growing older and older }\end{array}$ & $\begin{array}{l}\text { discussing a baby that gets } \\
\text { older }\end{array}$ \\
\hline 9 & recasts & $\begin{array}{l}\text { it doesn't } \\
\text { matter how old } \\
\text { you are, you } \\
\text { have to help and } \\
\text { share }\end{array}$ & $\begin{array}{l}\text { huh, this is all about sharing } \\
\text { and helping }\end{array}$ & discussing page 133 \\
\hline 10 & $\begin{array}{l}\text { non-corrective } \\
\text { repetition }\end{array}$ & $\begin{array}{l}\text { they are } \\
\text { different } \\
\text { families taking } \\
\text { care of one } \\
\text { another }\end{array}$ & $\begin{array}{l}\text { uh ha, they are different } \\
\text { families }\end{array}$ & $\begin{array}{l}\text { discussing the different } \\
\text { families in the book }\end{array}$ \\
\hline 11 & $\begin{array}{l}\text { non-corrective } \\
\text { repetition, } \\
\text { clarification } \\
\text { requests, } \\
\text { metalinguistic } \\
\text { feedback/clues }\end{array}$ & $\begin{array}{l}\text { they go from } \\
\text { newborn, } \\
\text { to a toddler } \\
\text { to teenager }\end{array}$ & $\begin{array}{l}\text { wow, they grow from } \\
\text { newborn, to a toddler } \\
\text { to teenager, what's a newborn }\end{array}$ & $\begin{array}{l}\text { discussing the different } \\
\text { stages of a person's life }\end{array}$ \\
\hline
\end{tabular}




\begin{tabular}{|c|c|c|c|c|}
\hline & feedback types & $\begin{array}{l}\text { student } \\
\text { response }\end{array}$ & teacher feedback & context \\
\hline 12 & recasts & $\begin{array}{l}\text { it's a baby that } \\
\text { just born or } \\
\text { couple of days } \\
\text { old }\end{array}$ & $\begin{array}{l}\text { so well say just to about } \\
\text { probably to six weeks }\end{array}$ & $\begin{array}{l}\text { describing the term } \\
\text { "newborn" }\end{array}$ \\
\hline 13 & $\begin{array}{l}\text { clarification } \\
\text { requests, } \\
\text { metalinguistic } \\
\text { feedback/clues }\end{array}$ & it's a timeline & why are we using a timeline & $\begin{array}{l}\text { teacher and para- } \\
\text { professionals put } \\
\text { a timeline on the board } \\
\text { with pictures of people } \\
\text { from newborn to senior } \\
\text { citizens }\end{array}$ \\
\hline 14 & $\begin{array}{l}\text { recasts, } \\
\text { metalinguistic } \\
\text { feedback/clues }\end{array}$ & $\begin{array}{l}\text { it showing from } \\
\text { baby and what } \\
\text { happens }\end{array}$ & $\begin{array}{l}\text { it's showing a chronology } \\
\text { of age from how we go from } \\
\text { newborn until we get older }\end{array}$ & $\begin{array}{l}\text { discussing the timeline } \\
\text { of a person's life }\end{array}$ \\
\hline 15 & $\begin{array}{l}\text { non-corrective } \\
\text { repetition }\end{array}$ & photos & they're photographs & $\begin{array}{l}\text { talking about the types } \\
\text { of pictures in the book }\end{array}$ \\
\hline 16 & $\begin{array}{l}\text { recasts, } \\
\text { acknowledgement }\end{array}$ & $\begin{array}{l}\text { I think they are } \\
\text { real }\end{array}$ & $\begin{array}{l}\text { alright, the pictures are } \\
\text { of real people }\end{array}$ & $\begin{array}{l}\text { discussing the types } \\
\text { of photographs }\end{array}$ \\
\hline 17 & recasts & $\begin{array}{l}\text { true narratives } \\
\text { about a lot } \\
\text { of things }\end{array}$ & $\begin{array}{l}\text { these are just vignettes of lots } \\
\text { of things }\end{array}$ & $\begin{array}{l}\text { talking about the different } \\
\text { families in the photos }\end{array}$ \\
\hline 18 & elicitation & $\begin{array}{l}\text { people get mad } \\
\text { but not forever }\end{array}$ & $\begin{array}{l}\text { so do you think we are talking } \\
\text { about the same persons, } \\
\text { sometimes they don't get } \\
\text { along, but you are not mad } \\
\text { forever, because you are } \\
\text { families }\end{array}$ & $\begin{array}{l}\text { discussing how some } \\
\text { families get mad at each } \\
\text { other }\end{array}$ \\
\hline 19 & recasts, elicitation & $\begin{array}{l}\text { you take care } \\
\text { of brothers and } \\
\text { sisters }\end{array}$ & $\begin{array}{l}\text { you should take care of them, } \\
\text { now who takes care of whom }\end{array}$ & $\begin{array}{l}\text { discussing the role } \\
\text { of brothers and sisters }\end{array}$ \\
\hline 20 & $\begin{array}{l}\text { clarification } \\
\text { requests, } \\
\text { metalinguistic } \\
\text { feedback/clues }\end{array}$ & $\begin{array}{l}\text { mom takes care } \\
\text { of the baby if he } \\
\text { cries }\end{array}$ & $\begin{array}{l}\text { is it only moms job to take } \\
\text { care of the baby }\end{array}$ & $\begin{array}{l}\text { discussing the role } \\
\text { of brothers and sisters }\end{array}$ \\
\hline 21 & recasts & $\begin{array}{l}\text { sometimes } \\
\text { brothers and } \\
\text { sisters }\end{array}$ & $\begin{array}{l}\text { sometimes it's the job } \\
\text { of brothers and sisters or }\end{array}$ & $\begin{array}{l}\text { discussing the role } \\
\text { of brothers and sisters }\end{array}$ \\
\hline 22 & acknowledgement & dads & okay & \\
\hline 23 & $\begin{array}{l}\text { non-corrective } \\
\text { repetition }\end{array}$ & $\begin{array}{l}\text { the older takes } \\
\text { care of the } \\
\text { younger }\end{array}$ & $\begin{array}{l}\text { the older takes care of the } \\
\text { younger }\end{array}$ & $\begin{array}{l}\text { discussing the role } \\
\text { of brothers and sisters }\end{array}$ \\
\hline 24 & $\begin{array}{l}\text { clarification } \\
\text { requests, } \\
\text { metalinguistic } \\
\text { feedback/clues }\end{array}$ & $\begin{array}{l}\text { twins mean they } \\
\text { are alike }\end{array}$ & $\begin{array}{l}\text { what do you mean alike, how } \\
\text { are they alike, in which way }\end{array}$ & $\begin{array}{l}\text { discussing the meaning } \\
\text { of the word twin }\end{array}$ \\
\hline
\end{tabular}




\begin{tabular}{|c|c|c|c|c|}
\hline & feedback types & $\begin{array}{l}\text { student } \\
\text { response }\end{array}$ & teacher feedback & context \\
\hline 25 & recasts & same hair & they have the same hair cut & $\begin{array}{l}\text { discussing similarities } \\
\text { of twins }\end{array}$ \\
\hline 26 & recasts & $\begin{array}{l}\text { they are born } \\
\text { at the same } \\
\text { time }\end{array}$ & $\begin{array}{l}\text { born at the same time, when } \\
\text { you are twins you are born } \\
\text { at the same time, you don't } \\
\text { have the same hair color, but } \\
\text { if they look alike they are } \\
\text { identical twins }\end{array}$ & $\begin{array}{l}\text { discussing that identical } \\
\text { twins are born at the same } \\
\text { time }\end{array}$ \\
\hline 27 & explicit correction & $\begin{array}{l}\text { but they don't } \\
\text { do the same } \\
\text { things }\end{array}$ & $\begin{array}{l}\text { no, they don't have to do } \\
\text { the same things }\end{array}$ & $\begin{array}{l}\text { discussing that identical } \\
\text { twins don't have to do } \\
\text { the same things }\end{array}$ \\
\hline 28 & recasts & $\begin{array}{l}\text { I have friends, } \\
\text { they are } \\
\text { identical twins } \\
\text { and I can't tell } \\
\text { them apart }\end{array}$ & $\begin{array}{l}\text { it's hard to tell identical twins } \\
\text { apart }\end{array}$ & $\begin{array}{l}\text { discussing how identical } \\
\text { twins look similar }\end{array}$ \\
\hline 29 & acknowledgement & $\begin{array}{l}\text { they can have } \\
\text { different hair } \\
\text { cuts }\end{array}$ & that's one way & $\begin{array}{l}\text { discussing how } \\
\text { to distinguish identical } \\
\text { twins }\end{array}$ \\
\hline 30 & acknowledgement & have name tags & that's an idea & $\begin{array}{l}\text { discussing how } \\
\text { to distinguish identical } \\
\text { twins }\end{array}$ \\
\hline 31 & acknowledgement & $\begin{array}{l}\text { have different } \\
\text { clothes }\end{array}$ & that would help & $\begin{array}{l}\text { discussing how } \\
\text { to distinguish identical } \\
\text { twins }\end{array}$ \\
\hline 32 & recasts & bracelets & oh name bracelets & $\begin{array}{l}\text { discussing how } \\
\text { to distinguish identical } \\
\text { twins }\end{array}$ \\
\hline 33 & recasts & birthmarks & $\begin{array}{l}\text { oh, birthmarks, even though } \\
\text { they are twins some of them } \\
\text { may have birthmarks and } \\
\text { some of them may not, but } \\
\text { unless it is visible on the face } \\
\text { or something }\end{array}$ & $\begin{array}{l}\text { discussing how } \\
\text { to distinguish identical } \\
\text { twins }\end{array}$ \\
\hline 34 & $\begin{array}{l}\text { non-corrective } \\
\text { repetition, } \\
\text { elicitation, } \\
\text { metalinguistic } \\
\text { feedback/clues }\end{array}$ & adopted & $\begin{array}{l}\text { adopted, I was hoping } \\
\text { someone would pick up this } \\
\text { word, what does it mean }\end{array}$ & $\begin{array}{l}\text { discussing adopted } \\
\text { children }\end{array}$ \\
\hline 35 & recasts & $\begin{array}{l}\text { my mom has } \\
\text { this baby, she } \\
\text { took it to the } \\
\text { foster house } \\
\text { and someone } \\
\text { came and took } \\
\text { the baby }\end{array}$ & $\begin{array}{l}\text { so they adopted the baby, } \\
\text { they make it their own }\end{array}$ & $\begin{array}{l}\text { discussing adopted } \\
\text { children }\end{array}$ \\
\hline
\end{tabular}




\begin{tabular}{|c|c|c|c|c|}
\hline & feedback types & $\begin{array}{l}\text { student } \\
\text { response }\end{array}$ & teacher feedback & context \\
\hline 36 & recasts & $\begin{array}{l}\text { you can't get } \\
\text { a baby then you } \\
\text { adopt }\end{array}$ & $\begin{array}{l}\text { yeah, there are a lot } \\
\text { of reasons why people adopt } \\
\text { a baby, some people can't } \\
\text { have a baby or some people } \\
\text { would like to have more } \\
\text { babies then they decide } \\
\text { to adopt, most of the times } \\
\text { people can't have babies and } \\
\text { would love to have a baby, } \\
\text { there are lots of people who } \\
\text { are orphans, who don't have } \\
\text { a home because their pass } \\
\text { away or whatever, they need } \\
\text { a home }\end{array}$ & $\begin{array}{l}\text { discussing adopted } \\
\text { children }\end{array}$ \\
\hline 37 & $\begin{array}{l}\text { acknowledgement, } \\
\text { clarification } \\
\text { requests, elicitation }\end{array}$ & $\begin{array}{l}\text { if you're } \\
\text { adopted and } \\
\text { people ask if } \\
\text { you are brother } \\
\text { and sister you } \\
\text { say yeah }\end{array}$ & $\begin{array}{l}\text { yeah, but legally what does } \\
\text { the word become, are you } \\
\text { born from the same mom and } \\
\text { dad }\end{array}$ & discussing adoption \\
\hline 38 & $\begin{array}{l}\text { clarification } \\
\text { requests }\end{array}$ & how do they fit & what do you mean & \\
\hline 39 & $\begin{array}{l}\text { clarification } \\
\text { requests, } \\
\text { metalinguistic } \\
\text { feedback }\end{array}$ & $\begin{array}{l}\text { how do they fit } \\
\text { in the house }\end{array}$ & $\begin{array}{l}\text { which house, the orphanage, } \\
\text { it's usually a huge place and } \\
\text { they can take a lot of them }\end{array}$ & discussing orphanage \\
\hline 40 & $\begin{array}{l}\text { clarification } \\
\text { requests }\end{array}$ & unintelligible & $\begin{array}{l}\text { these are adopted how can } \\
\text { you tell }\end{array}$ & \\
\hline 41 & $\begin{array}{l}\text { acknowledgement, } \\
\text { non-corrective } \\
\text { repetition }\end{array}$ & $\begin{array}{l}\text { it's under } \\
\text { the picture }\end{array}$ & right, it's under the picture & $\begin{array}{l}\text { noticing the wording } \\
\text { under the pictures }\end{array}$ \\
\hline 42 & explicit correction & $\begin{array}{l}\text { can a child go } \\
\text { where he wants } \\
\text { to go }\end{array}$ & $\begin{array}{l}\text { no, if the child is not an adult, } \\
\text { it's up to the agency and } \\
\text { the people involved only } \\
\text { when you are an adult, this } \\
\text { is when you are } 18 \text { and older } \\
\text { can you say where you want } \\
\text { to go, that is an interesting } \\
\text { question }\end{array}$ & $\begin{array}{l}\text { discussing a child's legal } \\
\text { rights }\end{array}$ \\
\hline 43 & elicitation & newborn & $\begin{array}{l}\text { what kind of a word is that, } \\
\text { thinking grammar }\end{array}$ & discussing vocabulary \\
\hline 44 & $\begin{array}{l}\text { clarification } \\
\text { requests }\end{array}$ & $\begin{array}{l}\text { a compound } \\
\text { word }\end{array}$ & $\begin{array}{l}\text { compound word, why is this } \\
\text { a compound word }\end{array}$ & discussing grammar \\
\hline 45 & $\begin{array}{l}\text { metalinguistic } \\
\text { feedback }\end{array}$ & $\begin{array}{l}\text { more than one } \\
\text { word }\end{array}$ & $\begin{array}{l}\text { it has "new" and "born" put } \\
\text { together }\end{array}$ & discussing grammar \\
\hline
\end{tabular}




\begin{tabular}{|c|c|c|c|c|}
\hline & feedback types & $\begin{array}{l}\text { student } \\
\text { response }\end{array}$ & teacher feedback & context \\
\hline 46 & $\begin{array}{l}\text { explicit correction, } \\
\text { elicitation }\end{array}$ & a toddler & $\begin{array}{l}\text { a toddler is a bit older, what } \\
\text { comes after a newborn }\end{array}$ & discussing age chronology \\
\hline 47 & $\begin{array}{l}\text { metalinguistic } \\
\text { feedback, } \\
\text { elicitation }\end{array}$ & the baby & $\begin{array}{l}\text { how old do you think is } \\
\text { a baby, a baby goes about } \\
\text { six weeks to a year and } \\
\text { a half, 6-8 months }\end{array}$ & discussing age chronology \\
\hline 48 & $\begin{array}{l}\text { non-corrective } \\
\text { repetition }\end{array}$ & $\begin{array}{l}\text { to make them } \\
\text { laugh }\end{array}$ & to make them laugh & $\begin{array}{l}\text { discussing how it is fun } \\
\text { to have a baby }\end{array}$ \\
\hline 49 & $\begin{array}{l}\text { acknowledgement, } \\
\text { recasts }\end{array}$ & $\begin{array}{l}\text { you can grab } \\
\text { them and hug } \\
\text { them }\end{array}$ & $\begin{array}{l}\text { right you can hug them, but } \\
\text { you have to be gentle and } \\
\text { careful }\end{array}$ & $\begin{array}{l}\text { discussing how it is fun } \\
\text { to have a baby }\end{array}$ \\
\hline 50 & $\begin{array}{l}\text { clarification } \\
\text { requests }\end{array}$ & $\begin{array}{l}\text { she pays } \\
\text { attention to the } \\
\text { baby }\end{array}$ & $\begin{array}{l}\text { does that mean she loves you } \\
\text { less }\end{array}$ & $\begin{array}{l}\text { discussing how a mother } \\
\text { spend more time with } \\
\text { the baby }\end{array}$ \\
\hline 51 & $\begin{array}{l}\text { non-corrective } \\
\text { repetition, } \\
\text { clarification } \\
\text { requests }\end{array}$ & $\begin{array}{l}\text { they're wearing } \\
\text { different } \\
\text { bracelets }\end{array}$ & $\begin{array}{l}\text { oh they are wearing different } \\
\text { bracelets, why do you } \\
\text { think that they are wearing } \\
\text { different bracelets }\end{array}$ & discussing page 135 \\
\hline 52 & $\begin{array}{l}\text { metalinguistic } \\
\text { feedback }\end{array}$ & younger & $\begin{array}{l}\text { oh, the older takes care of the } \\
\text { younger, that's not old, older } \\
\text { like you having a younger } \\
\text { brother or sister }\end{array}$ & $\begin{array}{l}\text { discussing the younger } \\
\text { and older person }\end{array}$ \\
\hline 53 & $\begin{array}{l}\text { non-corrective } \\
\text { repetition, } \\
\text { elicitation }\end{array}$ & $\begin{array}{l}\text { the big sister } \\
\text { is taking care } \\
\text { of the little } \\
\text { sister }\end{array}$ & $\begin{array}{l}\text { taking care of the little } \\
\text { sister, how old do you think } \\
\text { the sister is, what age }\end{array}$ & $\begin{array}{l}\text { discussing the role } \\
\text { of brothers and sisters }\end{array}$ \\
\hline 54 & recasts & $\begin{array}{l}\text { it's hard to be } \\
\text { younger because } \\
\text { your bigger } \\
\text { sister can do } \\
\text { more things }\end{array}$ & $\begin{array}{l}\text { so this is about younger and } \\
\text { older }\end{array}$ & $\begin{array}{l}\text { discussing the younger } \\
\text { and older person }\end{array}$ \\
\hline 55 & $\begin{array}{l}\text { clarification } \\
\text { requests }\end{array}$ & $\begin{array}{l}\text { it's like } \\
\text { a bumblebee }\end{array}$ & $\begin{array}{l}\text { does it mean that he is like } \\
\text { an animal }\end{array}$ & $\begin{array}{l}\text { trying to get the meaning } \\
\text { of the word "pest" }\end{array}$ \\
\hline 56 & $\begin{array}{l}\text { non-corrective } \\
\text { repetition }\end{array}$ & $\begin{array}{l}\text { it's like } \\
\text { bothering him }\end{array}$ & $\begin{array}{l}\text { yes, it's annoying, he bothers } \\
\text { him, he bothers him }\end{array}$ & $\begin{array}{l}\text { discussing the problems } \\
\text { with brother and sisters }\end{array}$ \\
\hline 57 & $\begin{array}{l}\text { non-corrective } \\
\text { repetition }\end{array}$ & $\begin{array}{l}\text { she's mean with } \\
\text { me }\end{array}$ & mean with you & $\begin{array}{l}\text { talk about a child whose } \\
\text { sister annoys him }\end{array}$ \\
\hline 58 & $\begin{array}{l}\text { non-corrective } \\
\text { repetition, recast }\end{array}$ & fight & $\begin{array}{l}\text { they fight, they argue, they } \\
\text { get mad at one another }\end{array}$ & $\begin{array}{l}\text { discuss how even adults } \\
\text { fight }\end{array}$ \\
\hline
\end{tabular}




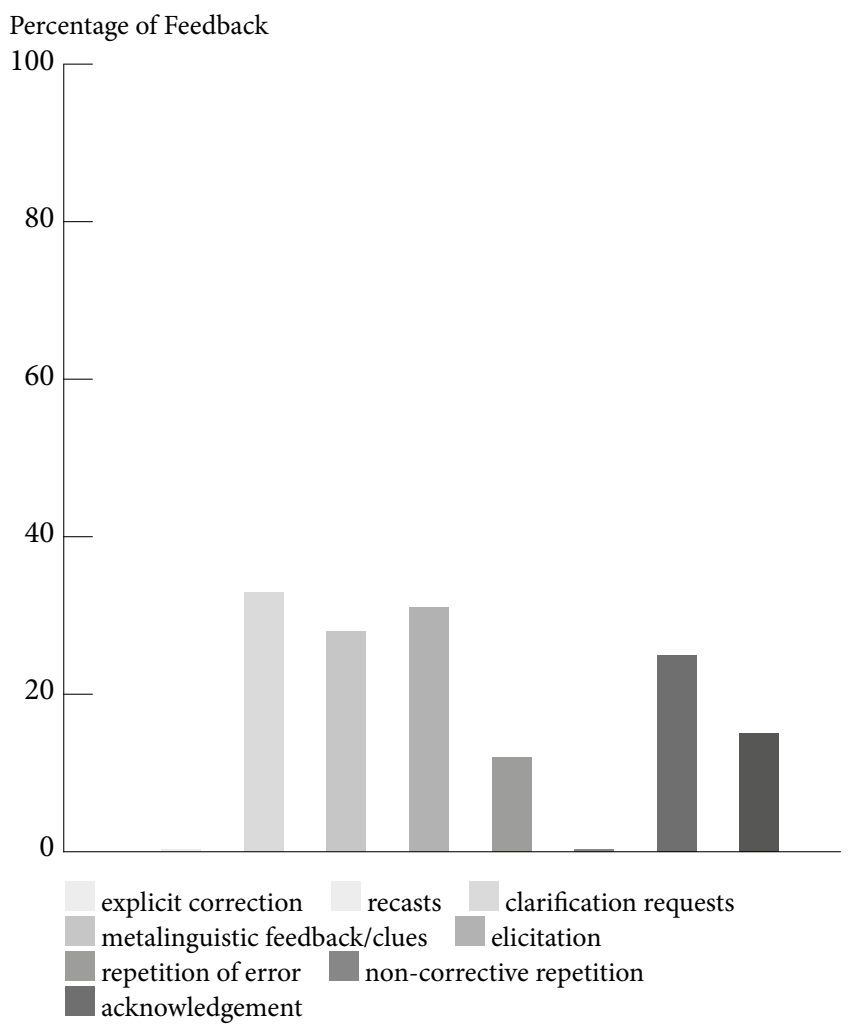

Figure 1. 58 Teacher Corrective Oral Fedback. Note: Explicit correction has $0.05 \%$ and is too small to show up on the graph.

\section{Results}

Some types of feedback were classified as acknowledgement, where the teacher acknowledges what the student has said and as non-corrective repetition, where the teacher simply repeated what was correctly stated (Gibbons, 2006, p. 52). Some of the feedback falls into more than one category i.e., number 6 is both non-corrective repetition and acknowledgement. It was considered whether to categorize some feedback as elaboration, where according to Gibbons, the student is encouraged to go into detail with what he/she has said, but it was decided not to because they could fall more into the category of clarification requests.

The findings from the data show that there were 58 teacher oral feedback points in approximately one hour of observation, equaling to almost 1 feedback point per minute. The breakdown of the types of feedback is as follows (see Figure 1 above): 3 explicit correction, 20 recasts, 16 clarification requests, 18 metalinguistic feedback or clues, 7 elicitation (all were "invite an open question method" and none were "fill in the blank" or "requires a reformulation of the incorrect speech"), 0 repetition of error, 15 non-corrective repetition and 11 acknowledgement. Although there were only 58 feedback points produced by the teacher, the breakdown shows 90 feedback points because some feedback was classified as more than one category. There were similarities between these findings and that of previous research (e.g., Lyster and Panova, 2002; Scott, 2008; Esmaeili, 2014), namely, recasts made up the highest percentage with $34 \%$.

\section{Limitation}

The data collection was limited to one observation with one teacher in one classroom, thus making it impossible to draw a conclusion to the second and third research questions: what kinds of corrective oral feedback lead to student repair and what kinds of corrective oral feedback do not lead to student repair. The corrective oral feedback in this classroom was made regarding content, not language. Therefore, to compare these data with the data of previous research where the data were collected from language classes would be problematic.

\section{Discussion}

It would be valuable to replicate and expand this study in a longitudinal research. Longitudinal research is necessary to see the consistency of the corrective oral feedback. Lightbown (2000) stated that to verify the success of CF in learners' interlanguage progress, researchers need to display that any effect is durable (Sheen, 2004, p. 266). This research could be expanded to include observations in schools with higher social economic status and with various student populations. Previous CF studies have not been investigated in the real school context, but rather in the context of a laboratory setting with NS-NNS dyads, for example, Carroll and Swain (1993), Leeman (2003), Long et al. (1998) which is unlike a classroom setting (Sheen, 2004, pp. 267-268). Such research could help to understand whether these findings are typical of classroom feedback or if they are similar to other classroom teacher feedback regardless of the social economic status and racial background.

The findings of this research on teacher corrective oral feedback are only a scratch of the surface and we are still far from comprehension of how feedback plays a role in the L2 learning process (Aljaafreh \& Lantolf, 1994, p. 466).

\section{References}

Aljaafreh, A., \& Lantolf, J. P. (1994, Winter). Negative feedback as regulation and second language learning in the zone of proximal development. The Modern Language Journal, 78(4), 465-483.

Bley-Vroman, R., \& Chaudron, C. (1994). Elicited imitation as a measure of second-language 
competence. In E. E. Tarone, S. M. Gass \& A. D. Cohen (Eds.), Research methodology in secondlanguage acquisition (pp. 245-261). Hillsdale, NJ: Lawrence Erlbaum.

Chaudron, C. (1988). Second language classrooms: Research on teaching and learning. New York, NY: Cambridge University Press.

de Gotari, B., \& Tedick, D. J. (1998, May). The bridge: From research to practice. Research on error correction and implications for classroom teaching. ACIE Newsletter, 1(3), 1-4.

DeKeyser, R. M. (1994). Implicit and explicit learning of second language grammar: A pilot study. TESOL Quarterly 28(1), 188-194.

Doughty, C., \& Varela, E. (1998). Communicative focus on form. In C. Doughty \& J. Williams (Eds.), Focus on form in classroom second language acquisition (pp. 114-138). New York, NY: Cambridge University Press.

Ellis, R. (2004). Editorial. Language Teaching Research, $8,235-239$.

Esmaeili, F. (2014, July). A study of corrective feedback and learner's uptake in classroom interactions. International Journal of Applied Linguistics and English Literature, 3(4). Retrieved from http://www. journals.aiac.org.au/index.php/IJALEL/article/ view/1165/1172

Gibbons, P. (2006). Bridging discourses in the ESL classroom: Student, teachers, and researchers. New York, NY: Continuum.

Han, Z. (2002, June). Rethinking the role of corrective feedback in communicative language teaching. RELC Journal, 33(1), 1-31.

Hammerly, H. (1987). The immersion approach: Litmus test of second language acquisition through classroom communication. Modern Language Journal, 7, 395-401.

Higgs, Th. V., \& Clifford, R. (1982). The push towards communication. In Th. V. Higgs (Ed.), Curriculum, competence, and the foreign language teacher ( $\mathrm{pp}$. 57-79). Lincolnwood, IL: National Textbook Company.

Larsen-Freeman, D. (2000). Techniques and principles in language teaching. Oxford, UK: Oxford University Press.
Lightbown, P. M. (1991). What have we here? Some observations on the role of instruction in second language acquisition. In R. Phillipson, E. Kellerman, L. Selinker, M. Sharwood Smith \& M. Swain (Eds.), Foreign/second language pedagogy research: A commemorative volume for Claus Faerch (pp. 197212). Clevedon, UK: Multilingual Matters.

Lightbown, P. M., \& Spada, N. (1993). Instruction and the development of questions in L2 classrooms. Studies in Second Language Acquisition, 15(2), 205-220.

Lightbown, P. M., \& Spada, N. (2006). How languages are learned (3rd ed.). Oxford, UK: Oxford University Press.

Lochtman, K. (2002). Oral corrective feedback in the foreign language classroom: How it affects interaction in analytic foreign language teaching. International Journal of Educational Research, 37, 271-283.

Lyster, R., \& Panova, I. (2002, Winter). Patterns of corrective feedback and uptake in an adult ESL classroom. TESOL Quarterly, 36(4), 573-595.

Lyster, R., \& Ranta, L. (1997). Corrective feedback and learner uptake. Negotiation of form in communicative classrooms. Studies in Second Language Acquisition, 20, 37-66.

Scott, E. (2008, Sept. 5). Corrective feedback in the language classroom: How to best point out language mistakes. Retrieved from http:// languagestudy.suite101.com/article.cfm/ corrective_feedback_in_the_language_classroom

Sheen, Y. (2004). Corrective feedback and learner uptake in communicative classrooms across instructional settings. Language Teaching Research, 8, 263-300.

Schmidt, R. (1990). The role of consciousness in second language learning. Applied Linguistics, 11, 129-58.

Schwartz, B. D. (1993). On explicit and negative data effecting and affecting competence and linguistic behavior. Studies of Second Language Acquisition, 15, 147-163.

White, L. (1991). Adverb placement in second language acquisition: Some effects of positive and negative evidence in the classroom. Second Language Research, 7, 133-161. 